\title{
Vaktaalrubriek
}

\section{Normtoets en ander terme: lesers se kommentaar}

\author{
W. van Z. de Villiers \\ Departement Stralingstegnologie, Atoomenergiekorporasic, Posbus 582, Pretoria, 0001
}

\begin{abstract}
'n Artikel oor 'n aantal nuwe terme wat in die Maart 1997nommer van hierdie Tydskrif verskyn het, ${ }^{1}$ het baie goeie reaksie uitgelok. Kommentaar en voorstelle is selfs van 'n leser in België ontvang! Dic terugvoer dui hopelik op 'n groter bewustheid dat die toekoms van Afrikaanse vaktaal grootliks bepaal sal word deur sy sprekers en sy vermoë om met ' $n$ voortdurende behoefte vir nuwe vakterminologie tred te hou.

Lesers se sterkste voorkeure en nuwe voorstelle ten opsigte van Afrikaanse ekwivalente vir die Engelse terme wat in genoemde artikel bespreek is, is met die Nasionale Terminologiediens en ander kundiges bespreek. Aanbevelings oor geskikte terme word hieronder gemaak.
\end{abstract}

\section{1. benchmark}

Dit is duidelik dat hierdie term vir die vergelyking van prosesse of stelsels met 'n bepaalde standaard om relatiewe prestasie te bepaal, reeds in verskeie vakgebiede inslag gevind het. Juis as gevolg van die wye gebruik daarvan, is dit baie moeilik om slegs een Afrikaanse term daarvoor te vind, hoewel daar uiteraard binne 'n bepaalde vakkonteks gestandaardiseer behoort te word. Aanvaarde ekwivalente is norm (as selfstandige naamwoord en byvoeglike naamwoord) en normtoets (as s.nw. en werkwoord) in die natuurwetenskappe, rekenaarwetenskap en ingenieurswese, en norm of baken in gebiede soos menslike hulpbronne en finansies.

Die volgende word dus voorgestel:

benchmark adj. : norm-

benchmark $v_{\text {. : : normtoets }}$

benchmark $\boldsymbol{n}$. : norm, normtoets

benchmarking : normtoetsing

benchmark problem : normtoetsprobleem

benchmark job : normpos, bakenpos

benchmark price : normprys, bakenprys

'n Leser het rigtinggewende publikasie vir 'n benchmark paper in ' $n$ bepaalde vakgebied voorgestel. Dit kan moontlik ook 'n bakenpublikasie genoem word. In landmeetkunde het bench mark die betekenis van 'n hoogtebaken of hoogtemerk (Geologiewoordeboek, 1996).

\section{2. hands-on training/experience}

Dic mening is deur verskeie lesers uitgespreek dat selfdoenmet do-it-yourself verwar kan word. Praktiese opleiding/ ondervinding is voorgestel, maar dit dra nie noodwendig die betekenis van die persoon se eie betrokkenheid by die opleiding voldoende oor nie. 'n Ander alternatief sou deelneemopleiding wees.

\section{3. abundance}

Solar abundance, wat na die voorkoms van elemente in die son verwys, is tevore algemeen met veelheid in die son vertaal.
In die nuwe Fisikawoordeboek wat tans voltooiing nader, word sonrykheid verkies. Isotoopveelheid word steeds vir isotopic abundance gebruik en isotoopverhouding vir abundance ratio.

\section{4. supercritical fluid extraction (SFE)}

Flutied asook vloeier word in die natuurwetenskappe en ingenieurswese vir fluid gebruik. Soos in die vorige artikel' aangetoon is, word kritiek as Afrikaanse ekwivalent vir critical aanbeveel. (Dit was egter uit lesers se kommentaar duidelik dat daar steeds 'n sterk voorkeur vir krities is!) Die skryfwyse van die Afrikaanse ekwivalent van bogenoemde term veroorsaak, soos te verwagte, groot probleme. Omdat ekstraksie met behulp van 'n superkritieke flü̈ed/vloeier gedoen word en die b.nw. dus op die eerste s.nw. in die samestelling betrekking het, moet die term as superkritiekefluted-ekstraksie (SFE) of superkritiekevloeier-ekstraksie geskryf word. (In daardie opsig is die term soortgelyk aan breërandhoed.) Die inskrywing by supercritical fluid chromatography in die Nuwe Chemiewoordeboek behoort ook hiervolgens aangepas te word.

\section{5. pregnant solution}

Dit val nie noodwendig lekker op die oor nie, maar dragtige oplossing is nog die mees aanvaarbare en gebruikte term. Dit is belangrik om dit te onderskei van versadigde en oorversadigde oplossing vir saturated en supersaturated solution, onderskeidelik.

\section{6. excipient}

Die mees aanvaarbare Afrikaanse term vir hierdie inerte stof wat tydens tabletvervaardiging by ' $n$ aktiewe geneesmiddel gevoeg word, is mengmiddel. Mengstof, bindmiddel en bindstof word ook gebruik. Draer word normaalweg vir carrier gebruik en is dus nie geskik in hierdie konteks nie.

\section{7. weatherability}

Verskeie lesers het uitgewys dat hierdie Engelse term, wat gebruik word om die weerstand of bestandheid van 'n dek- of beskermingslagie teen die weer (atmosferiese toestande) aan te dui, eintlik die teenoorgestelde beteken! Ons moet dus vermy om dieselfde fout in Afrikaans te maak. Om daardie rede word weerbestandheid of weervastheid voorgestel.

\section{8. strain layer}

Vervormingslaag word as Afrikaanse ekwivalent vir die term aanbeveel. Indien daar 'n nodigheid is om meer spesifiek aan te dui dat die lagie self nie noodwendig vervorming ondergaan nie, maar primêr dien om vervorming in die lagies aan weerskante daarvan te verhoed, kan dit 'n teenvervormingslaag genoem word.

(Vervolg op bl. 144 


\title{
Algemene artikels en berigte
}

\section{Die voorkoms van beroepsdoofheid en tinnitus by industriële werkers van Bloemfontein}

\author{
D.J. van den Heever*, S. Visser en D. van Aard \\ Technikon Vrystaat, Departement Omgewingswetenskappe, Privaat sak X20539, Bloemfontein, 9300
}

Ontvang; 2 Januarie 1996; anvalar 28 Julie 1997

\section{UITTREKSEL}

Geraas-gë̈nduseerde gehoorverlies word as een van die belangrikste bedryfsgevare beskou. Die gehoorstatus van industriele werkers is van groot belang, aangesien oormatige blootstelling aan harde, steurende on moontlik gevaarlike geraas, veral vir industriële werkers in Suid-Afrika, algemeen is en werkers nie doeltreffend teen geratsblootstelling beskerm word nie. Oormatige blootstelling aan geraas veroorsak dat die haarselle in die binne-oor degenereer wat uiteindelik sal lei tot permantente gehoorverlies. Die studie is gedurende 1993 uitgevoer om 'n verteenwoordigende profiel van industriële werkers in Bloemfontein se gehoorstatus te verkry. Nadat geralasopnames in verskeie soorte industrië̈ uitgevoer is, is werkers van vier verskillende industrieë ewekansig geselekteer om oudiometriese toetse te ondergan. Suiwertoon-oudiometrie is volgens intemasionale metodes aitgevoer nadat 'n otoskopiese ondersoek op elke werker gedoen is. Vraelyste is deur werknemers voltooi om die mediese en gehoorgeskiedenis van die proefpersone te bekom.

Die resultate van die studie dui aan dat geen betekenisvolle verskille $(P<0,05)$ tussen ouderdom en gehoorverlies bestaan nie, en dus daarop dai dat gehoorafname by proefpersone nie net weens ouderdom plaasvind nie, maar wel as gevolg van oormatige geraasblootstelling. Die gemiddelde persentasie binourale gehoorverlies van werkers is tot soveel as $15 \%$ in sommige van die industrië̈ bereken. Die resultate beklemtoon die implementering van gehoorbehoudprogramme in industrieë van Bloemfontein, ten einde geraasgeinduseerde gehoorverlies te voorkom. Weens die gebrek aan doeltreffende wetstoepassing en beroepsgesondheidswetgewing gedurende die afgelope 50 jaar, word ook verwag dat die resultate van hierdie studie vir die meeste industrieë in Suid-Afrika verteenwoordigend is.

\begin{abstract}
The occurrence of occupational deafness and tinnitus in industrial workers of Bloemfontein

Noise-induced deafness is regarded as one of the most important occupational dangers. The hearing status of industrial workers is of great concern due to the fact that most workers working in large factories, are exposed to loud, excessive, irritating and probably dangerous noise in their work environment. Excessive exposure to noise causes cells in the inner ear to degenerate which eventually can lead to permanent hearing loss. This study was conducted during 1993 to obtain a representative profile of the hearing status of industrial workers in Bloemfontein and to determine if the workers protected their ears. After noise surveys had been conducted in various industries, the workers of four randomly selected different industries were audiometrically tested. Pure-tone audiometry was used according to international methods after an otoscopic examination was carried out on each test person. Questionnaires were used to obtain medical and hearing histories of the test persons.

The results of the study showed no significant difference $(P<0,05)$ between age and hearing loss which indicated that hearing loss did not occur naturally, due to excessive noise exposure. The mean percentage of hearing loss was calculated at $15 \%$ for workers in some of the industries. The results emphasised the importance of implementing hearing conservation programmes in Bloemfonteins' industries in order to prevent hearing loss. Due to the lack of efficient occupational health legislation and the application thereof during the past 50 years, it is expected that the results of this study will be representative of most industries in South Africa.
\end{abstract}

\section{INLEIDING}

Geraas word gewoonlik as dic subjektiewe oordecl van 'n ongewensde klank beskou.' Geraas wat die gevolg van talle aktiwiteite is, word as een van die toenemende besoedelingsvorme beskou wat weens industriêle ontwikkeling kan ontstaan. Dit is algemeen bekend dal chroniese blootstelling aan geraas, geraasgeïnduseerde dootheid by mense kan veroorsaak. Die ouditiewe effekte van geraas behels die inmenging van klankwaarneming deur die indusering van gehoorverlies, asook dic maskering van gewenste klanke soos waarskuwingseine in die werkomgewing.'

Dic voorkoms van geraas-geïnduseerde gehoorverlies is reeds gedurende die sewentiende ecu deur Bernardo Ramazinni, die vader van die beroepsgeneeskunde, gedokumenteer (Rom 1992). ${ }^{2}$ Geraas-geïnduseerde gehoorverlies word mettertyd onomkeerbaar en die gevolge daarvan kan deur' $n$ werker ervaar word selfs nadat blootstelling aan geraas gestaak is.'

Dit is algemeen bekend dat geraas een van dic grootste beroepsgesondheidsrisiko's vir die mens en spesifiek vir werkers in industricë is. Dic Nasionale Instiluut vir Beroepsgesondheid en Veiligheid in dic VSA het geraas-geïndusecrde gehoorverlies recls in 1985 as een van dic eerste tien berocpsicktes geklassifiseer. ${ }^{2}$ Volgens Moss en Parsons (1986) ${ }^{3}$ het onlangse sudies bewys dat ongeveer 7,4 tot 10,2 miljoen mense in die VSA in omgewings werk wat skadelik vir hulle gehoor is. Daar is ook gevind dat ongeveer $3,2 \%$ van al die werkers die een of ander 
mate van gehoorverlies hel. Gehoorverlies vererger gewoonlik met ' $\mathrm{n}$ toename in ouderdom. $\mathrm{en}$ is ook meer ernstig by werkers van industricë wat as raserig geklassifiseer word tecnoor dié wat as sogenaamd stil geklassifiseer word $(<85 \mathrm{~dB}(\mathrm{~A}))$. $^{+}$

Die belangrikheid van ' $n$ behoorlike bepaling van die skade wat 'n persoon as gevolg van geraasblootstelling opdoen, kan nooit onderskat word nic. ' $n$ Persoon wat aantoon dat hy gehoorskade in ' $n$ industric opgedoen hel, kan wel deur dic vergoedingskommisaris finansicel vergoed word. Ten spyte hicrvan moet daar klem gelê word op dic feit dat gehoorskade permanent en onomkeerbaar is. Dit beteken dat sodanige persoon die res van sy lewe vir sekere klanke of geluide doof sal wees.

Alhoewel sekere werkareas of pligte in industriee ' $n$ gehoorskaderisiko inhou, is sommige industriece se risiko groter as dić van ander. In veral die petroleum-, hout- of voedselprosesseringsbedryf word sovecl as $25 \%$ van dic werksmag aan geraasvlakke bokant $85 \mathrm{~dB}$ blootgestel. ${ }^{2}$ Dic vervaardiging van meubels, metale, rubber of plastick het ook eiesoortige geraasblootstellingsrisiko's daaraan verbonde indien 'n persoon nic sy gehoor docltreffend beskerm nic.

Geraas-geinduseerde gehoorverlies word gewoonlik op twee manicre veroorsaak, naamlik akute of chroniese blootstelling. In hicrdic studie is daar slegs op die effek van chroniese geraasblootstelling in tradisioncel raserige industriee gekonsentreer.

Die doel van hierdie studic was dus om 'n gehoorstatusprofiel van werkers in vier tradisioneel raserige industrie ce waarin die ekwivalente A-beswaarde klankdrukpeile groter as $85 \mathrm{~dB}(\mathrm{~A})$ is, te verkry. Die persentasie gehoorverlies van die proefpersone wat gehoorverlies getoon het, is ook met hulle ouderdom vergelyk om 'n moontlike korrelasic te bepaal.

\section{METODES}

Industriële siftingsoudiometrie is volgens SABS-gebruikskode 083 van $1993^{5}$ op werkers van vier lukraak geselekteerde raserige industrieë ( $\mathrm{Neq}>85 \mathrm{~dB}(\mathrm{~A})$ ) uitgevoer. Industriële werkers van ' $\mathrm{n}$ asbes-sementaanleg $(\mathrm{n}=151)$, kocldrankinmaakaanleg $(\mathrm{n}=$ 36), melkverwerkingsaanleg $(n=43)$ en werknemers van die nasionale weermag se meganiese werkswinkels ( $n=91$ ), is gedurende die studic as proefpersone geselekteer. 'n Vraclys is gebruik waarin inligting soos die werker se ouderdom, getal jare diens, stokperdjies, militêre diens en siektetoestande verkry is. ${ }^{\prime}$

Drie Tremetrics RA400-oudiometers is vir die bepaling van die werkers se gehoordrempels gebruik. Die oudiometers is deur 'n goedgekeurde laboratorium (Amtronix Edms. Bpk.) volgens SABS-gebruikskode 0145 van $1983^{\circ}$ gekalibreer en die kalibrasic is daagliks met behulp van 'n Tracor Oscar III akoestiese oor nagegaan. Toetsfrekwensies van $500 \mathrm{~Hz}, 1000$ $\mathrm{Hz}, 2000 \mathrm{~Hz}, 3000 \mathrm{~Hz}, 4000 \mathrm{~Hz}, 6000 \mathrm{~Hz}$ en $8000 \mathrm{~Hz}$ is gebruik om albei ore om die beurt vir die kwantifisering van gehoorverlies te toets. Die toetse is in 'n klankdigte vertrek, wat aan die bepalings van SABS-gebruikskode 0182 van $1982^{7}$ vir siftingsoudiometrie voldoen, in duplikaat uitgevoer.

Die toetsprosedure is voor die aanvang van elke tocts mondelings aan die proefpersone verduidelik. Otoskopiese ondersoeke is deur die oudiometris op elke proefpersoon uitgevoer om te verseker dat sigbare oorinfeksie of abnormaliteite nie teenwoordig is nie. 'n Gesondheidsvraclys is ook deur elke proefpersoon voltooi. Dic oorfone is op die proefpersone se ore geplaas en 'n sein is daardeur aangebied. Daar is van die proefpersone verwag om die responsknop te druk wanneer die klank gehoor is. Die resultate van elke toets is daarna met behulp van 'n rekenaarprogram (HCSIII) verwerk en 'n toctsverslag is uitgereik.
Gedurende die studie is die monourale gehoorverlies met behulp van die formule wat deur die Suid Afrikaanse vergoedingskommissaris gedurende 1993 gebruik is, bereken':

Gehoorverlies vir' $n$ gegewe oor $=\frac{\mathrm{G}_{a v}-26}{92-26}$

waar $G_{a v}=\frac{\left(D_{500}+D_{10 \times x)}+D_{2(x \times x)}\right)}{3}$

en $D_{5(0)}, D_{10 \times x)}$ en $D_{2000}=$ gehoordrempelpeil vir $500,1000 \mathrm{cn}$ $2000 \mathrm{~Hz}$.

Die binourale verlies is dan:

$=\frac{(5 \times \% \text { vir beter oor }+1 \times \% \text { vir swakker oor })}{6}$

\section{RESULTATE EN BESPREKING}

In figuur 1 word die voorkoms van tinnitus by die werkers van dic onderskeic industricë aangetoon wat laag blyk te wees. $26 \%$ van die werkers in die asbes-sementaanleg en $4,8 \%$ van dic verdedigingsmagte se werkers het aangetoon dat hulle tinnitus ondervind. Alhoewel geeneen van dic werkers van die ander twee aanlegte aangedui het dat hulle tinnitus ondervind nic, word dit wel verwag dat die toestand ook daar sal voorkom. 'n Moontlike verklaring vir die afwesigheid van tinnitus by die laasgenoemde werkers mag wees dat die werkers dit deurgaans weens blootstelling aan hoë klankdrukpeile ondervind en dit dus nic as abnormaal beskou nic. 'n Verdere verklaring mag ook wees dat hulle wel nic tinnitus ondervind nic, aangesien beide industrieë gedurende dic afgelope twee jare toesien dat gehoorbeskerming deurentyd deur hulle werknemers gedra word. Die meeste van die werkers in hierdie studie het ook nooil voorheen enige gehoorsorg of voorligting met betrekking tot gehoorbeskerming ontvang nic, wat tot onkunde rakende dic tocstand bydra.

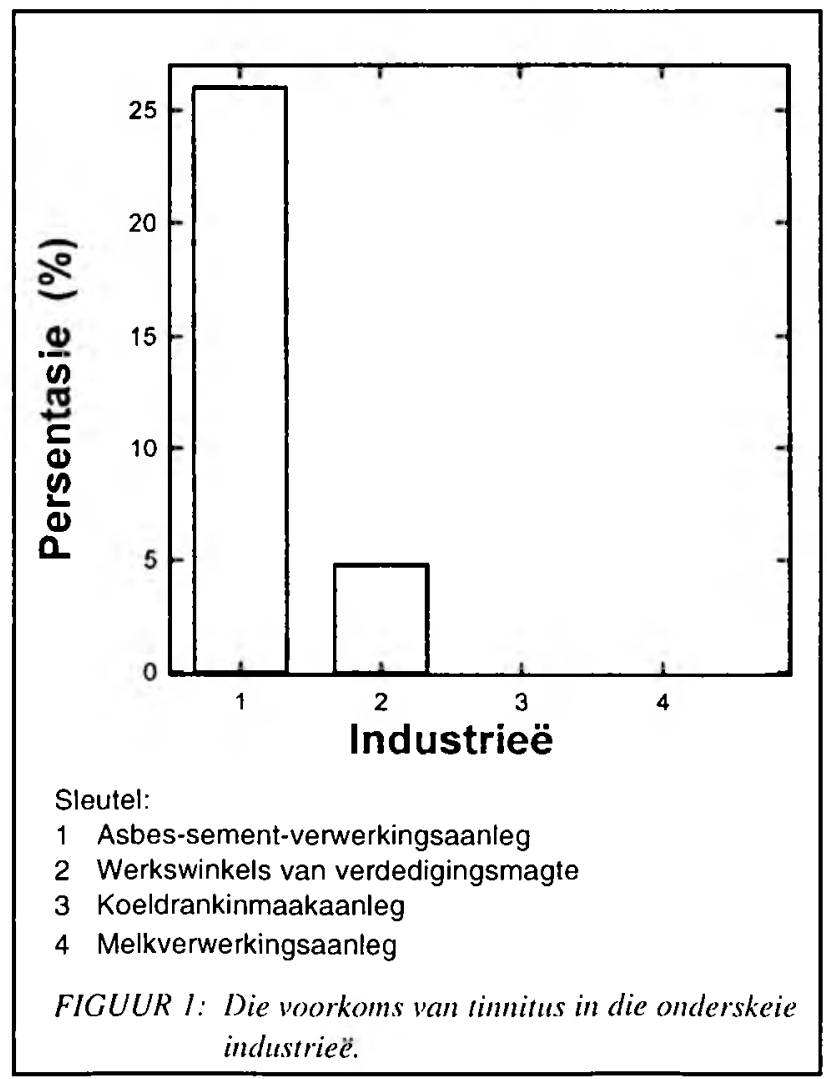


In figuur 2 word die gemiddelde persentasie monorale gehoorverlies van werkers in dic onderskeic industrieë aangetoon. Die hoogste persentasies is by die melkverwerkingsaanleg met waardes van $23,5 \pm 23,45 \%$ vir linkerore en $15,2 \pm 33,6 \%$ vir regterore gevind. Alhoewel die werkers van die asbessementaanleg die hoogste persentasic tinnitus (figuur 1) ondervind, het hulle dic minste gehoorverlies tydens die studie getoon. Dit is duidelik dat alle werkers in die studie meer skade in hulle linkerore ondervind en dus kan aangeneem word dat
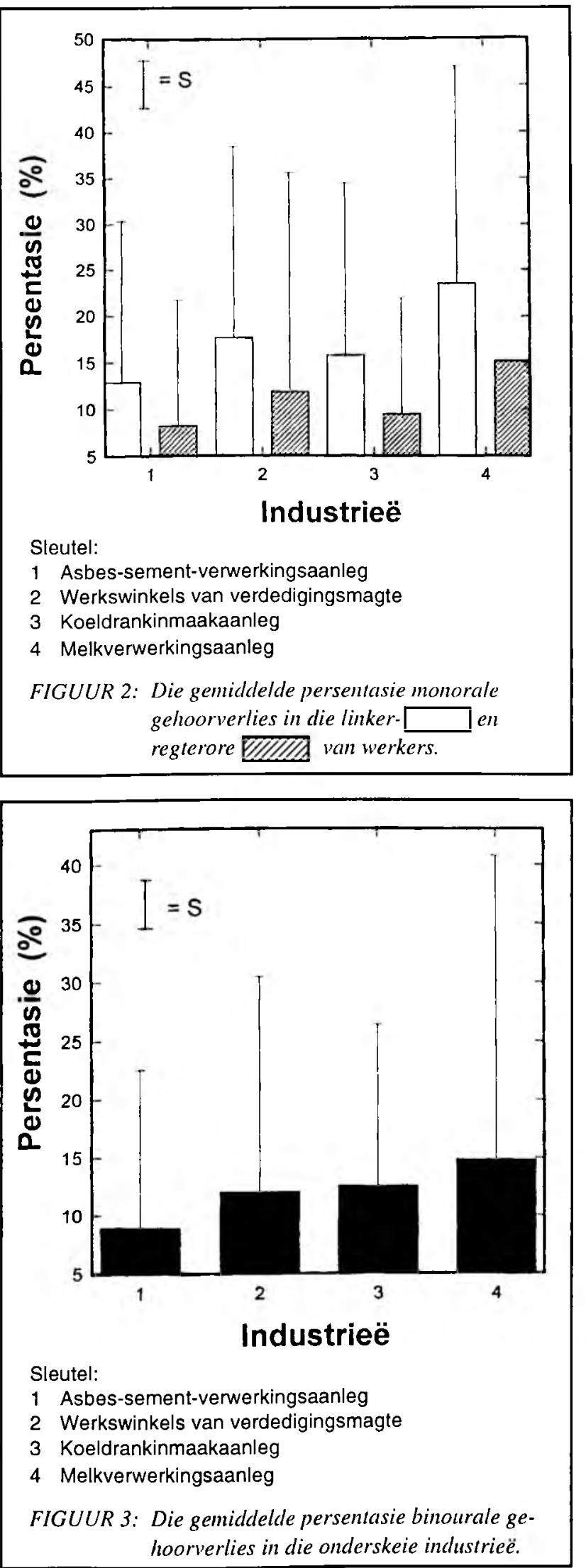

hulle die beste met hulle regterore sal kan hoor. Geen werklike verklaring vir hierdie lendens kan gegee word nie, alhoewel dit in verskeic sludies bewys is dat regshandige persone swakker gehoor in hul linkerore en andersom het. ${ }^{8}$

Figuur 3 dui die gemiddelde persentasic binourale gehoorverlies van werkers in die onderskeie industrieë aan. 'n Laagste waarde van $8,9 \pm 13,6 \%$ is vir werkers in die asbes-sementananleg en 'n hoogste waarde van $14,8 \pm 25,9 \%$ is vir werkers in die melkverwerkingsaanleg bereken. Volgens Milne (1979)" kan sovecl as $40 \%$ binourale gehoorverlies voorkom sonder dat 'n werker daarvan bewus is. Dit veroorsalak dat dit mocilik kan wees om woorde wat baic medeklinkers bevat, selts by frekwensies so hoog soos $10000 \mathrm{~Hz}$, te kan hoor of identiliseer. Dit het dus ook 'n veiligheidsrisiko tot gevolg weens die moontlike misinterpretasie van boodskappe of werksopdragte. Die grool standaardafwyking wat aangetoon word, is te wyte aan die groot variasies in blootstellingstyd (jare diens) en ouderdom van die proefpersone.

In figuur 4 word die korrelasie tussen ouderdom en gehoorverlies van die werkers aangedui. 'n Korrelasiekoëlfisiënt van 0,09 is bereken wat aandui dat verskeic laktore bo en behalwe ouderdom 'n nadelige invloed op die gehoor van die persone het. Die frekwensies hoër as $4000 \mathrm{~Hz}$ word veral in die geval van ouderdomsdoofheid geaffektecr. Volgens Schröder en Schoeman (1989)' word die onderskeid lussen presbikuse en geraasdoolheid met toename in geraas en ouderdom bemoeilik, vanweë die verspreiding van geraasdoolheid aan naburige frekwensies.

Alhocwel 'n positiewe regressic (+ 1) tussen ouderdom en gehoorverlies verwag word, bewys die studie dat dit nie in gevalle geld waar persone aan industrièle geraas blootgestel word en gehoorbeskerming agterweè gelaat word nie. Jonger werkers is dus net so vatbaar vir gehoorskade in 'n geraasarea as 'n ouer persoon. Dit beklemtoon die dra van gehoorbeskermers om gehoordoeltrellendheid te bewaar.

\section{SAMEVATTING}

Alhoewel geraas 'n pertinente deel van die industriële werksomgewing uitmaak, hoef gehoorverlies nie deel daarvan te wees nic. Die resultate van hierdie studie beklemtoon die voorkoms van geraas-geinduseerde gehoorverlies wanneer werkers met onvoldoende of geen gehoorbeskerming aan geraas in hulle

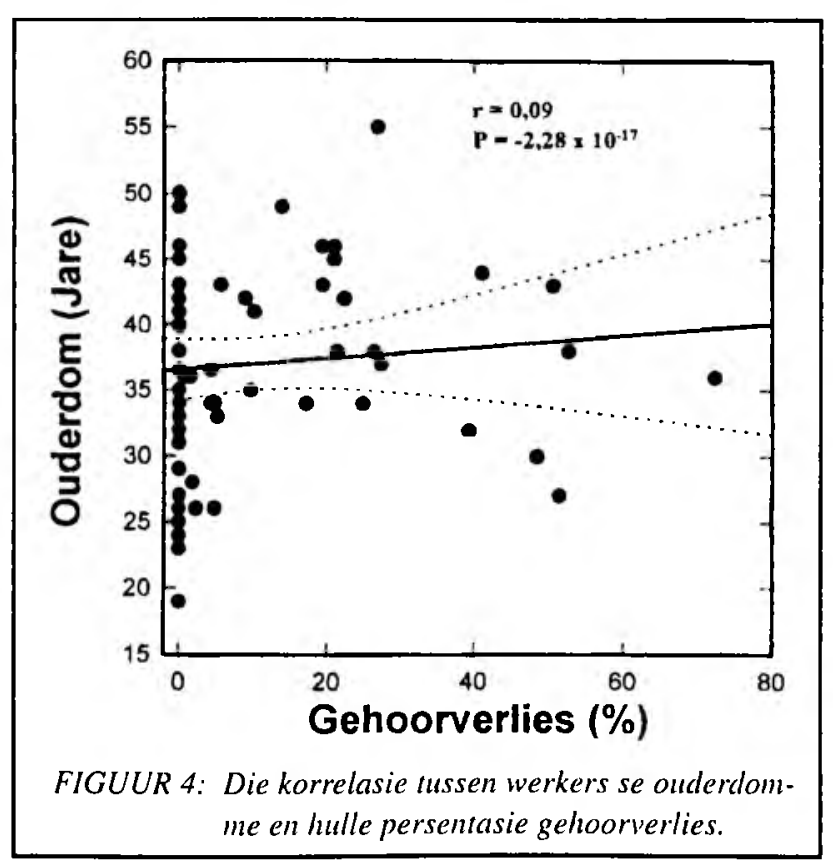


werkplek blootgesicl word. Indien werkers steeds aan die huidige toestande en klankdrukpeile blootgestel word, sal 'n beduidende hoeveelheid geraas-geindusecrde gehoorverlies na chroniese blootstelling by alle werkers aanwesig wees.

\section{SUMMARY}

It is well known that occupational exposure to excessive noise ( $>85 \mathrm{~dB}$ ) may cause hearing loss to exposed workers. A study was conducted to obtain a representative profile of the hearing status of industrial workers in Bloemlontein. After noise surveys were conducted in various industries, the workers of four randomly selected different industries were audiometrically tested. Pure-tone audiometry was used according to international methods alter an otoscopic examination by an audiometrist was carried out on each test person. Questionnaires were used to obtain medical and hearing histories of the test persons. Percentages of hearing loss were calculated for each industry which ranged from $8,9 \pm 13,6$ to $14,8 \pm 25,9$.

\section{Methods}

Industrial screening audiometry was conducted on all the employees according to SABS code 083 of 1983. Workers from an asbestos-cement plant ( $n=151)$, a solt drink canning plant $(n=$ 36), a milk bottling plant $(n=43)$ and the workshops of the national defence force $(n=91)$ were selected for tests. Three Tremetrics RA400 audiometers were used for the testing of the workers. The audiometers were calibrated according to SABS code 0145 of 1983 and the tests were conducted in a sound proof room which complies with the specifications as set in SABS code 0182 of 1982. The test procedures were explained to the test persons beforehand and the results were processed with a computer. Percentage hearing loss was calculated according to the formula as described by Schröder and Schoeman (1989). ${ }^{1}$

\section{Results}

The results of the study showed no significant difference $(\mathrm{P}<0,05)$ between age and hearing loss which indicated that hearing loss did not only occur because of natural ageing, but as a result of excessive noise cxposure. The mean percentage binaural hearing loss was calculated at as high as $15 \%$ for workers in some of the industries. Monaural hearing loss ranged from below $10 \%$ to as high as $23 \%$ in the study group and tinnitus was experienced up to $26 \%$.

\section{Conclusion}

It is evident that the workers tested in this study do not protect their ears sufficiently and therefore, their hearing is in a bad state. If they are exposed to the current conditions and sound pressure levels, a significant amount of noise-induced hearing loss will be present after chronic exposure.

\section{LITERATUURVERWYSINGS}

1. Schröder, H.H.E., Schoeman, J.J. (1989). Inleiding tot Beroepshigienne (OHASA Goodwood) pp. 195 - 236.

2. Rom, W.M. (1992). Environmental and Occupational Medicine. Sccond ed. (Little, Brown and Co., Boston) p.1/21.

3. Moss, A.J., Parsons, V.L. (1986). Current Estimates from the National Health Interview Survey - United States, Vital Health Stat.

4. Self-reported hearing loss among workers potentially exposed to industrial noise - (1988). United States. $M M W R$, 259, 2213-2217.

5. SABS (SUID-AFRIKAANSE BURO VIR STANDAARDE). (1989). Gebruikskode vir die meet en beoordeling van arbeidsgeraas vir gehoorbehouddoeleindes. Die Raad vir die S.A. Buro vir Standaarde, Pretoria.

6. SABS (SUID-AFRIKAANSE BURO VIR STANDAARDE). (1983). Gebruikskode vir nagaan van luggeleidingskalibrering van suiwertoonoudiometers. Die Raad vir die S.A. Buro vir Standaarde, Pretoria.

7. SABS (SUID-AFRIKAANSE BURO VIR STANDAARDE). (1982). Gebruikskode vir die verkryging van 'n akoestiese ongewing wat vir oudiometriese toetse geskik is. Die Raad vir die S.A. Buro vir Standaarde, Pretoria.

8. Dufresne, R.M., Alleyne, B.C., Reesal, M.R. (1987). Asymmetric hearing loss in truck drivers, Ear and Hearing, 9(1), 41-42.

9. Milne, A. (1979). Noise pollution impact and contermeasures (David \& Charles. London) p. 83.
(Vervolg vanif bl. 140)

Slot

Ek bedank graag die volgende persone en instansies vir hul kommentaar, voorstelle en hulp: al die lesers en organisasies wat op bogenoemde artikel gereageer het, die Nasionale Terminologiediens, dr. D.F. Louw, die Bestuur van die Afdeling
Chemiese Wetenskappe van die SA Akademic en kollegas wat hulp verleen het.

\section{LITERATUURVERWYSING}

1. De Villiers, W. van Z. (1997). Normtocts, selfdoenopleiding, superkritick en nog baic meer, S.Afr: Tydskr: Natulurwet. en Tegnol., 16, 30. 